\title{
Forecasting the Demand for Medical Tourism in India
}

\author{
Anu Rai ${ }^{1}$, Premangshu Chakrabarty ${ }^{2}$, Ashis Sarkar ${ }^{3}$ \\ ${ }^{I}$ (Research Scholar, University of Kalyani, Nadia, West Bengal, India) \\ ${ }_{2}^{2}$ Associate Professor, Department of Geography, Vishwa Bharti University, Shantiniketan, West Bengal, India) \\ ${ }^{3}$ (Professor, Department of Geography, Chandernagore College, Chandannagar, West Bengal, India)
}

\begin{abstract}
The purpose of this study is to predict as precisely as possible the medical tourism demand in India. As tourist arrivals is the most frequently used measure of tourism demand, the present study considers FTAs and their purpose of visit to India as a measure of inbound tourist to seek medical care. The medical tourism demand and its potential market till 2015 are identified based on available appropriate model as suited to the nature of data specific to individual country.
\end{abstract}

Keywords: Forecast, Opportunity, Medical Tourist, Tourist Arrivals.

\section{Introduction}

An amalgamation of two distinct service sector 'healthcare' and 'tourism' with niche service features, medical tourism industry is one of the fastest growing service sectors of $21^{\text {st }}$ century. The sector is growing exponentially and has emerged as a major force for the growth of service exports worldwide. With the availability of high quality healthcare services at affordable rate; increased role of information and communication channels; wider range of healthcare services from traditional to modern one, India is one of the major players in this multi-billion industry. In fact India's effort to promote medical tourism took off in the late 2002 after the Mckinsey - CII (2002) outlined immense potential of this sector. The following efforts were made:

- to modernize and expand airports in the country and to improve road connectivity and other infrastructural facilities,

- to promote many hospitals as centre of excellence in its tourism brochure,

- to ease the medical tourist arrivals ' $\mathrm{M}$ ' and ' $\mathrm{MX}$ ' visa is introduced,

- to avail tax concessions, medical tourism is declared as service sector,

- National Accreditation Board for Hospitals established to promote quality care of healthcare institutions,

- at the state level Kerala, Karnataka, Maharashtra and Gujarat have made many concerned efforts to promote healthcare tourism

As a result of such measures, the total FTAs in India of 6.57 million, $2.6 \%$ were for medical treatments in 2012. Its foreign exchange earnings from medical tourism are estimated to be around US $\$ 1.8$ billion in 2010 (Shanmugam, 2013) ${ }^{[1]}$. In fact Medical Tourism Climate Survey Report 2014 conducted by IMTEC states that India is second largest country after Thailand in accommodating foreign patients (IMTJ, 2014) ${ }^{[2]}$. Since 2000's the number of such travellers has been increasing by at least $25 \%$ every year. This situation shows that medical tourism in India is passing through a process of dynamic change. The market has been growing rapidly and is playing an increasingly important role in international tourism trade and trade relations. The forecasting of tourism demand and mapping of the potential market is therefore an essential prerequisite for planners and decision - makers that aims at cost efficient investments in the planning of capacity expansion and long term decision making related to investments (Huang, 2012) ${ }^{[3]}$. In lieu of this the present study will try to project the number of medical tourist arrivals from various country of nationality till 2015 as precisely as possible based on available models as suited to the nature of data specific to individual country. Since the data on the number of medical tourist arrivals and their country of nationality is not readily available, this report will significantly help decision makers for long term decision making for sustainability of medical tourism industry in India.

\section{Database and Methodology}

Tourism demand is usually regarded as a measure of visitors' use of goods or services. The objective of tourism demand forecasting is to predict the most probable level of demand that is likely to occur in the light of known circumstances. Among many measures including variety of units like national currency, nights, days, distances travelled, passengers seats occupied and accommodation facility used, tourist arrivals is the most frequently used measure of tourism demand (Fretchling, 2001) ${ }^{[4]}$. The present study considers Foreign Tourist Arrivals (FTAs) and their purpose of visit as a measure inbound medical tourism demand forecasting for India. 
The number of quarterly and annual FTAs from different countries to India cover the period of first quarter of 2003 to last quarter of 2012 were used to predict total tourism demand up to 2015 as precisely as possible based on available appropriate models as suited to the nature of data specific to individual country. Quarterly FTAs data are provided by Ministry of Tourism, Government of India ${ }^{[\mathrm{i}}$. Time Series Modeler of IBM - SPSS 19.0 is used to build best - fit time series model to individual country covers following steps:

\subsection{Building Models}

The Time Series Modeler procedure creates models for time - series and produces forecast. It works on an assumption that a model of the series that explained the past values may also predict whether and how much the next few values will increase or decrease. It includes an Expert Modeler that automatically determines the best model for each of your time series, thus eliminating the need to identify an appropriate model through trial and error. Table 1 shows various best - fit models chosen by Expert Modeler for individual countries.

Table 1 Model Description

\begin{tabular}{|c|c|c|}
\hline Model & $\begin{array}{l}\text { Country of } \\
\text { Nationality }\end{array}$ & Model Type \\
\hline \multirow{31}{*}{ 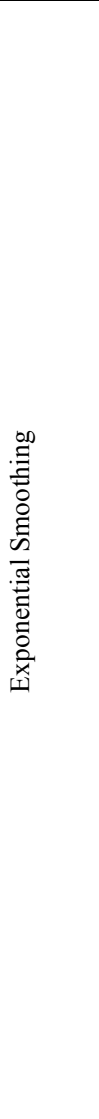 } & Argentina & Winters' Multiplicative \\
\hline & Brazil & Winters' Multiplicative \\
\hline & Austria & Winters' Multiplicative \\
\hline & Denmark & Winters' Multiplicative \\
\hline & Finland & Winters' Multiplicative \\
\hline & Germany & Winters' Multiplicative \\
\hline & Ireland & Winters' Multiplicative \\
\hline & Norway & Winters' Multiplicative \\
\hline & Portugal & Winters' Multiplicative \\
\hline & Sweden & Winters' Multiplicative \\
\hline & Switzerland & Winters' Multiplicative \\
\hline & UK & Winters' Multiplicative \\
\hline & Kazakhstan & Winters' Multiplicative \\
\hline & Poland & Winters' Multiplicative \\
\hline & Ukraine & Winters' Multiplicative \\
\hline & Egypt & Winters' Multiplicative \\
\hline & Kenya & Winters' Multiplicative \\
\hline & South Africa & Winters' Multiplicative \\
\hline & Israel & Winters' Multiplicative \\
\hline & Myanmar & Winters' Multiplicative \\
\hline & Australia & Winters' Multiplicative \\
\hline & New Zealand & Winters' Multiplicative \\
\hline & Canada & Winters' Additive \\
\hline & USA & Winters' Additive \\
\hline & Mexico & Winters' Additive \\
\hline & Belgium & Winters' Additive \\
\hline & France & Winters' Additive \\
\hline & Greece & Winters' Additive \\
\hline & Netherlands & Winters' Additive \\
\hline & Russian Fed. & Winters' Additive \\
\hline & Sudan & Winters' Additive \\
\hline \multirow{18}{*}{ 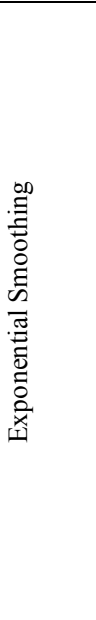 } & Tanzania & Winters' Additive \\
\hline & Bahrain & Winters' Additive \\
\hline & Iraq & Winters' Additive \\
\hline & Oman & Winters' Additive \\
\hline & Saudi Arabia & Winters' Additive \\
\hline & Turkey & Winters' Additive \\
\hline & Nepal & Winters' Additive \\
\hline & Sri Lanka & Winters' Additive \\
\hline & Bhutan & Winters' Additive \\
\hline & Indonesia & Winters' Additive \\
\hline & Malaysia & Winters' Additive \\
\hline & Philippines & Winters' Additive \\
\hline & Singapore & Winters' Additive \\
\hline & Vietnam & Winters' Additive \\
\hline & China (M) & Winters' Additive \\
\hline & Japan & Winters' Additive \\
\hline & Rep. of Korea & Winters' Additive \\
\hline & Others & Winters' Additive \\
\hline
\end{tabular}




\begin{tabular}{|c|c|c|}
\hline & Italy & Simple Seasonal \\
\hline & Spain & Simple Seasonal \\
\hline & UAE & Simple Seasonal \\
\hline & Iran & Simple Seasonal \\
\hline & Pakistan & Simple Seasonal \\
\hline & China (Taiwan) & Simple Seasonal \\
\hline \multirow{7}{*}{ 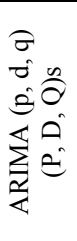 } & Bangladesh & $\operatorname{ARIMA}(2,0,0)(0,0,0)$ \\
\hline & Nigeria & $\operatorname{ARIMA}(0,1,0)(1,1,0)$ \\
\hline & Yemen & $\operatorname{ARIMA}(0,1,0)(1,1,0)$ \\
\hline & Afghanistan & $\operatorname{ARIMA}(0,0,1)(0,1,0)$ \\
\hline & Maldives & ARIMA $(0,0,1)(0,1,0)$ \\
\hline & Thailand & $\operatorname{ARIMA}(0,0,0)(0,1,0)$ \\
\hline & Czech Republic & $\operatorname{ARIMA}(0,0,0)(0,1,0)$ \\
\hline
\end{tabular}

\subsection{Modeling Method and Assumption}

For automatic time series forecasting of FTAs in India, the default method of Expert Modeler is chosen. By default, the Expert Modeler considers both exponential smoothing and ARIMA models of forecasting.

\subsubsection{Exponential Smoothing}

ES methods are classified as seasonal or non - seasonal. It summarizes each value of a time series with an average of recent values. It can be also defined as a weighted moving average with weights that decline exponentially into the past. The main difference among the various exponential smoothing methods is the way they treat the trend and seasonality (Cuhadar, 2014) ${ }^{[6]}$. Default Expert Modeler selects Winters' Multiplicative, Additive and Simple Seasonal Exponential Smoothing method for given countries as shown in Table 1. Winters' Multiplicative model is appropriate for series with a linear trend and a seasonal effect that depends on the level of the series. Its smoothing parameters are level, trend and season.

The basic equations for Winters' multiplicative method often known as Holt-Winters Multiplicative Method can be defined as follows:

Level: $\quad L_{t}=d \frac{A_{t}}{S_{t-1}}+(1-a)\left(L_{t-1}+b_{t-1}\right)$

Trend: $\quad b_{t}=\beta\left(L_{t}-L_{t-1}\right)+(1-\beta) b_{t-1}$

Seasonal: $\quad S_{t}=\gamma \frac{A_{t}}{L_{t}}+(1+\gamma) S_{t-s+h}$

Forecast:

$$
F_{t+h}=\left(L_{t}+h b_{t}\right) S_{t-s+h}
$$

Winters' Additive model is appropriate for series with a linear trend and a seasonal effect that does not depend on the level of the series. Its smoothing parameters are level, trend and season. The equation for Winters' Additive method is as follows:

Level: $\quad L_{t}=\alpha\left(A_{t}-S_{t-1}\right)+(1-\alpha)\left(L_{t-1}+b_{t-1}\right)$

Trend: $\quad b_{t}=\beta\left(L_{t}-L_{t}\right)+(1-\beta) b_{t-1}$

Seasonal: $\quad S_{t}=\gamma\left(A_{t}-L_{t}\right)+(1-\gamma) S_{t-s}$

Forecast: $\quad F_{(t+h)}=\left(L_{t}+S_{t-s+h}\right)$

Simple Seasonal model is appropriate for series with no trend and a seasonal effect that is constant over time. Its smoothing parameters are level and season. It can be described by the following equations:

Level: $\quad L_{t}=\alpha\left(A_{t}-S_{t-s}\right)+(1-\alpha)\left(L_{t-1}\right)$

Seasonal: $\quad S_{t}=\gamma\left(A_{t}-L_{t}\right)+(1-\gamma) S_{t-s}$

Forecast: $\quad F_{(t+h)}=\left(L_{t}+S_{t-s+h}\right)$ 
Where, $L=$ level of the series

$\alpha=$ level smoothing constant between 0 and 1

$A=$ actual values

$s=$ number of seasonal periods in a year (as four quarters here)

$b=$ trend of the series

$\beta=$ seasonal smoothing constant between 0 and 1

$S=$ seasonal component

$\gamma=$ seasonal smoothing constant between 0 and 1

$t=$ some time period

$h=$ number of time periods ahead to be forecast

\subsubsection{ARIMA Model}

ARIMA model building method is an empirically driven methodology of systematically identifying, estimating, diagnosing and forecasting time series (Cuhadar, 2014) ${ }^{[7]}$. Popularly known as the Box - Jenkins approach this method searches for the combination of two forecasting method and their parameters that minimize the error in simulating the past series. The two methods are Auto-regression (AR) and Moving Average (MA). The acronym ARIMA is used to identify the Autoregressive Integrated Moving Average Method (Fretchling, 2001) ${ }^{[8]}$, where ' $I$ ' indicate the 'integration index' which is a number of times a series must be differenced to achieve stationarity. The general form of the ARIMA Model is written as the following formulas - $\operatorname{ARIMA}(p, d, q)(P, D, Q) s$ which indicates as follows:

- Autoregressive $(p)$ : the number of autoregressive orders in the model. Autoregressive orders specify which previous values from the series are used to predict current values. For example, an autoregressive order of 2 specifies that the value of the series two time periods in the past be used to predict the current value.

- Difference $(d)$ : specifies the order of differencing applied to the series before estimating models. Differencing is necessary when trends are present (series with trends are typically non-stationary and ARIMA modeling assumes stationarity) and is used to remove their effect. The order of differencing corresponds to the degree of series trend 1 st order differencing accounts for linear trends, $2^{\text {nd }}$ order accounting for quadratic trends and so on.

- Moving Average $(q)$ : the number of moving average orders in the model. Moving average orders specify how deviations from the series mean for previous values are used to predict current values. For example, moving average orders of 1 and 2 specify that deviations from the mean value of the series from each of the last two time periods be considered when predicting current values of the series.

- $\quad P$ : is the number of parameters in Autoregressive Seasonal Model

- $D$ : the seasonal differencing degree

- $Q$ : the number of parameters in moving average seasonal model and

- $s$ : the period of seasonality

It can be written as: $\quad\left[\emptyset_{p}(B) \Phi_{P S}\left(B^{S}\right) \nabla^{d} \nabla^{D S} X_{t}=\theta_{q}(B) \Theta_{Q S}\left(B^{s}\right)_{a t}\right]$

Where, $X_{t}=$ the observed value at time point $\mathrm{t}$ (or transformed value)

$\emptyset_{p}(B)=$ the AR or Autoregressive operator i.e. $\left[\left(1-\emptyset_{1} B-\emptyset_{2} B^{2}-\ldots-\emptyset_{2} B^{p}\right)\right]$

$B=$ the backshift operator $\left[B X_{t}=X_{t-1}\right]$

$\Phi_{P S}\left(B^{S}\right)=$ the seasonal AR Model $\left[\left(1-\Phi_{1} B^{s}-\Phi_{2} B^{2 S}-\ldots-\Phi_{P} B^{P S}\right)\right]$

$B^{S}=$ the seasonal backshift operator $\left[B^{S} X_{t}=X_{t-s}\right]$

$\nabla^{d}=$ the differencing operator $\left[\nabla^{d} X_{t}=(1-B)^{d} X_{t}\right]$

$\nabla^{D S}=$ the seasonal differencing operator $\left[\nabla^{D S} X_{t}=\left(1-B^{S}\right)^{D} X_{t}\right]$

$a_{t}=$ the random error at time point ' $t$ ' $\left[a_{t} \sim N\left(0, \sigma^{2} a\right)\right]$

$\theta_{q}(B)=$ the moving average operator $\left[1-\theta_{1} B-\theta_{2} B^{2}-\ldots-\theta_{1} B^{q}\right]$ and

$\Theta_{Q S}\left(B^{s}\right)=$ seasonal moving average operator $\left[\left(1-\Theta_{I}\left(B^{S}\right)-\Theta_{2} B^{2 S}-\ldots-\Theta_{Q} B^{Q S}\right)\right]$

\subsection{Forecast Accuracy Evaluation}

Accuracy testing is the most important tourist demand forecast evaluation criterion. The accuracy of a forecasting model depends on how close the forecast values of $F_{t}$ are to the actual value of $A_{t}$. The magnitude of the forecasting error allows the analyst to evaluate the performance of the forecasting procedures across time periods in the series. Among many measures of forecast accuracy, MAPE or Mean Absolute Percentage Error is 
often used to test forecasting accuracy. It is the error magnitude measures compute percentage errors relative to the values in the historical series. It is independent of the units used and can therefore be used to compare series with different units. It can be expressed as -

$$
\text { MAPE }=\frac{1}{n} *\left(\left|\frac{e_{t}}{A_{t}}\right| * 100\right)
$$

Where, $\mathrm{n}=$ number of periods

$e=$ forecast error i.e. $\left[e=A_{t}-F_{t}\right]$

$A=$ actual value of the variable being forecast

$t=$ some time period

$F=$ forecast value

As a rule, lower MAPE values are preferred to higher ones because they indicate a forecasting model is producing smaller percentage errors. Lewis (1982) has suggested the following interpretation of MAPE values (Fretchling, 2001) ${ }^{[9]}$ :

- less than 10 per cent is highly accurate forecasting

- between 10 and 20 per cent is good forecasting

- between 20 and 50 per cent is reasonable forecasting

- greater than 50 per cent is inaccurate forecasting

However demand of tourism is an outcome of highly complex human behavior but Lewis's interpretation is often used to judge MAPE values (Çuhadar, 2014) ${ }^{[10]}$. Therefore, comment on reliability of forecasting accuracy is made on the basis of MAPE value following Lewis's interpretation.

\subsection{Generating Tourist Forecast and Estimating Potential Medical Tourist Arrivals to India}

The aforesaid forecasting models are applied and projected number of FTAs till 2015 is generated. Country - wise data on the proportion of FTAs for the medical treatment, compiled by the Ministry of Tourism through disembarkation cards which have the provision for recording the purpose of the visit for each foreign tourist is selected to estimate the number of medical tourists till 2015. It is believed that the proportion of FTAs for medical treatment recorded for 2012 if extrapolated for the year 2014 \& 2015, would give an estimated number of tourists nationality wise who are visiting India to undergo various medical treatments.

\section{Projecting Demand for Medical Tourism in India}

The empirical results of applied forecasting models which depict the projected number of FTAs to India up to 2015 have been shown in Table 2. It is projected that in 2015, India will host largest number of foreign tourists from USA (1255959), UK (809262) and Bangladesh (475643) followed by Sri Lanka, Germany, France, Canada and so on as shown in Fig. 1.

To measure forecast accuracy MAPE, the most widely used method is applied following Lewis's interpretation. Fig. 2 depicts reliability level of each forecasting model applied to individual country. It is noticed that the MAPE varies from a minimum of 3.20 per cent to 26.88 per cent across all models. It depicts that most of the forecasting models applied fall under good category of forecasting with less than 20 per cent of forecasting error except Kazakhstan, Myanmar, Russia, Bhutan, UAE and Pakistan which are reasonable or acceptable with more than 20 per cent of error.

The observed and estimated number of tourist arrivals to India for medical treatment from different country of nationality since 2009 to 2015 is shown in Table 3. Numerically, it is noticed that among different nationals the medical tourist arrivals in India is led by third world countries include Bangladesh, Maldives, Afghanistan, Iraq, Nigeria together with Russia, Oman, Sri Lanka, UAE, USA and so on (Fig. 3)

The estimated value depicts that in 2015 India will host maximum number of medical tourist arrivals from Afghanistan (36973), Maldives (36657), and Bangladesh (36625) followed by Nigeria, Iraq, Russia, Oman, Sri Lanka and so on (Fig. 4 and Fig. 5). 


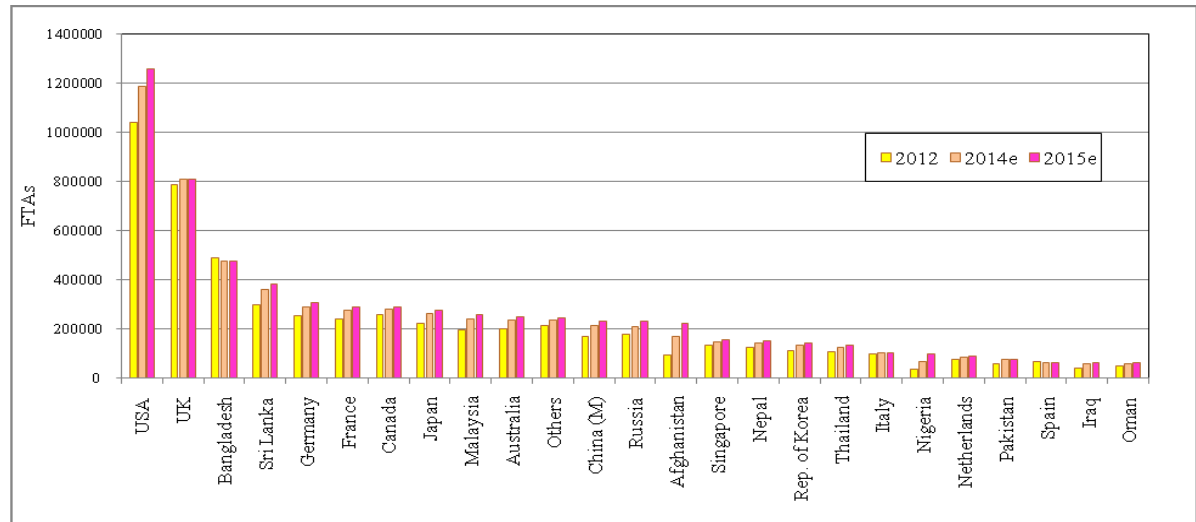

Figure 1 Estimated Foreign Tourist Arrivals in India (2014 - 2015)

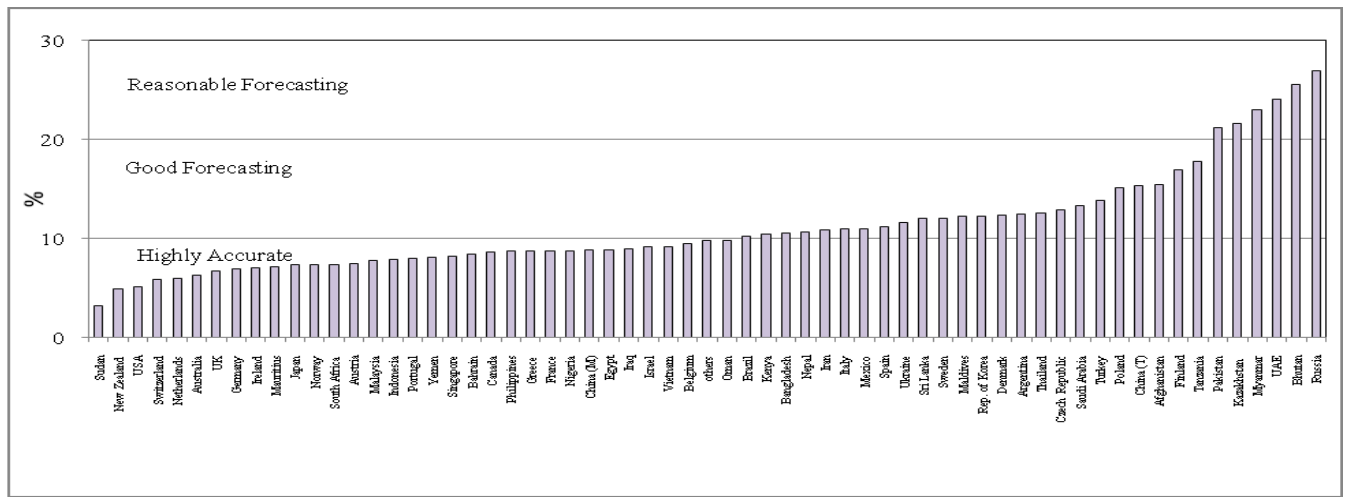

Figure 2 MAPE Plot - Testing Forecasting Accuracy (after Lewis, 1982)

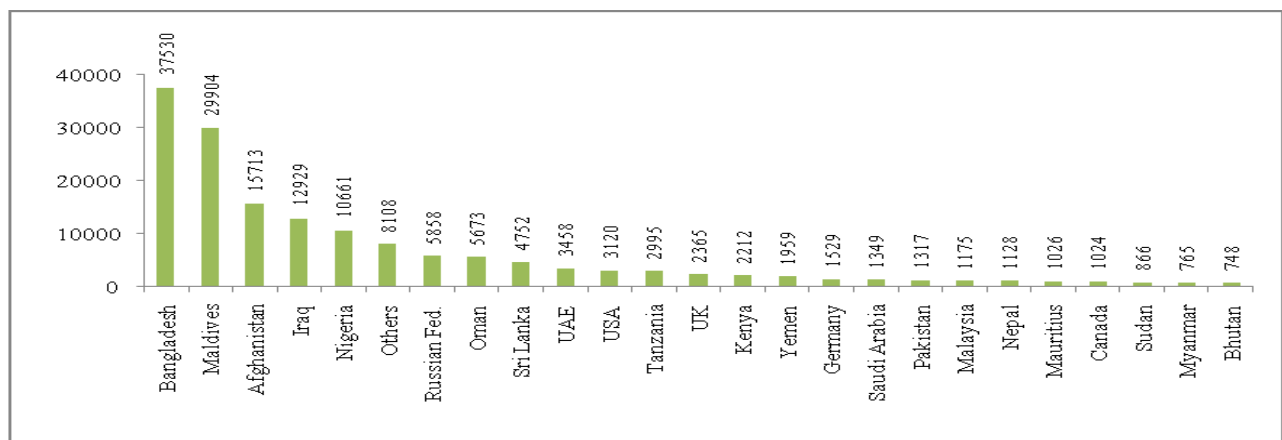

Figure 3 Foreign Tourist Arrivals to India for Medical Treatment, India Tourism Statistics, 2012.

\section{Conclusion}

No doubt India has many advantages in health and medical tourism market varies from cost advantages, no waiting time, advanced medical infrastructure to the domain of holistic and traditional healthcare system. Many migrating patients in search of better opportunity of medical care have already chosen India as their destination for medical treatments. But observed number of medical tourist arrivals from different countries depicts that in spite of many healthcare advantages, India still accommodate large number of patients from third world nations including Bangladesh, Maldives, Afghanistan, Iraq and Nigeria followed by others (Fig. 5) and the trend being estimated to be same for 2015. However there is an opportunity of hosting maximum number of foreign tourists from USA, UK, Germany, France, and Canada where demand of outbound medical tourism is very high because of high cost of treatment to long waiting list (Mishra, 2012) ${ }^{[1]}$ but still in order to explore the untapped potential of these developed nations' market India has to make some effective measures on the status of community health and hygiene and need based infrastructure especially in terms of connectivity, safety and security for the visitor travelling in the country. 


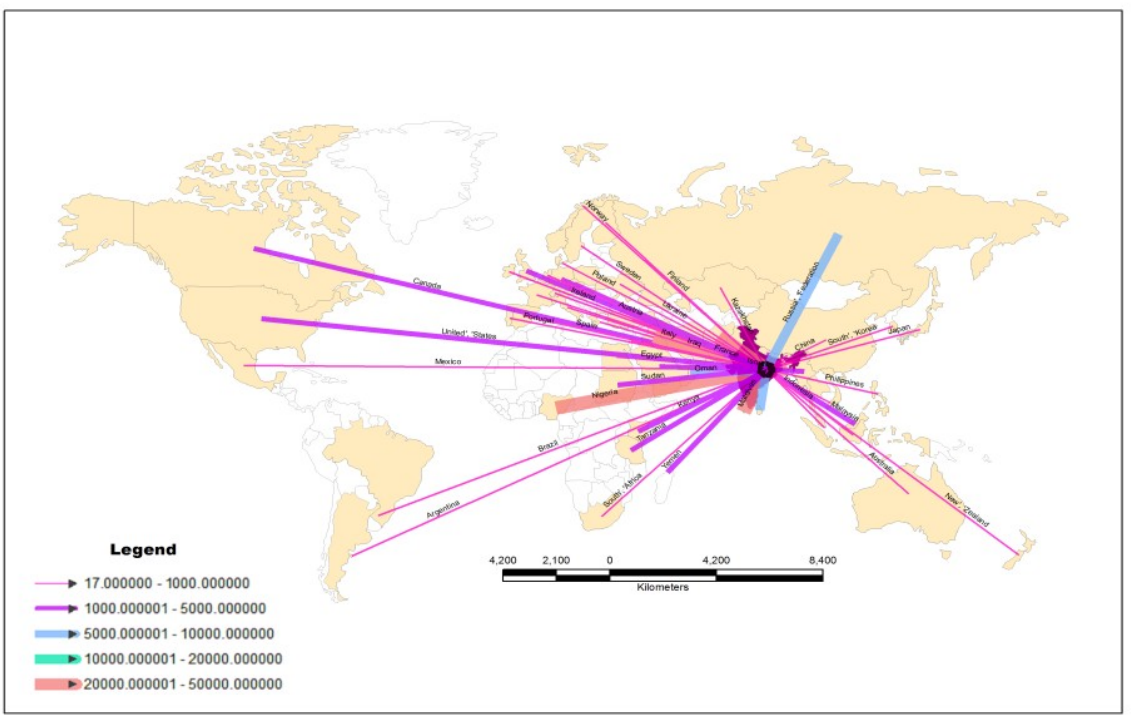

Figure 4 Mapping the Potential Market of Medical Tourism, 2015

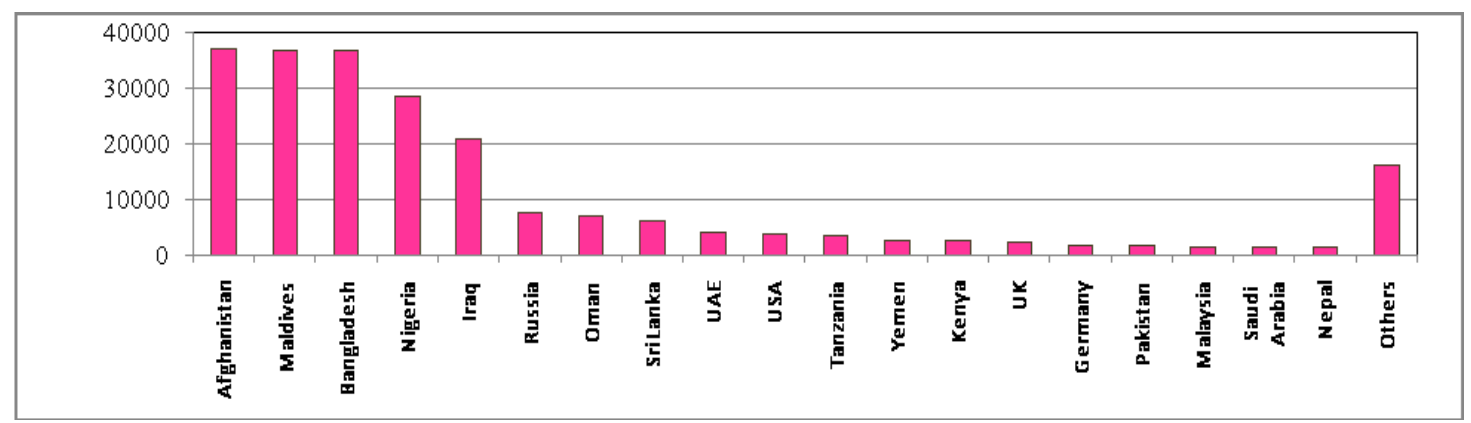

Figure 5 Projected Medical Tourist Arrivals to India, 2015

Table 2 Projected Foreign Tourist Arrivals to India (2013 - 2014)

\begin{tabular}{|c|c|c|}
\hline \multirow{2}{*}{ Country of Nationality } & \multicolumn{2}{|c|}{ Forecast } \\
\hline & 2014 & 2015 \\
\hline Argentina & 10001 & 10974 \\
\hline Brazil & 21319 & 22626 \\
\hline Austria & 41324 & 43328 \\
\hline Denmark & 33866 & 33479 \\
\hline Finland & 25939 & 27247 \\
\hline Germany & 289126 & 307891 \\
\hline Ireland & 28491 & 30227 \\
\hline Norway & 27303 & 29064 \\
\hline Portugal & 28299 & 30056 \\
\hline Sweden & 57169 & 60602 \\
\hline Switzerland & 54321 & 56639 \\
\hline UK & 808093 & 809262 \\
\hline Kazakhstan & 13887 & 15120 \\
\hline Poland & 27038 & 26883 \\
\hline Ukraine & 39627 & 42830 \\
\hline Egypt & 12787 & 13515 \\
\hline Kenya & 38385 & 40116 \\
\hline South Africa & 52522 & 55285 \\
\hline Israel & 47384 & 48645 \\
\hline Myanmar & 36723 & 40127 \\
\hline Australia & 233815 & 249114 \\
\hline New Zealand & 44999 & 47863 \\
\hline Canada & 279401 & 287678 \\
\hline
\end{tabular}


Forecasting the Demand for Medical Tourism in India

\begin{tabular}{|c|c|c|}
\hline USA & 1187861 & 1255959 \\
\hline Mexico & 13498 & 14375 \\
\hline Belgium & 48057 & 50627 \\
\hline France & 276390 & 291030 \\
\hline Greece & 8524 & 8971 \\
\hline Netherlands & 83430 & 86997 \\
\hline Russia & 209667 & 229572 \\
\hline Sudan & 11780 & 12884 \\
\hline Tanzania & 24061 & 25486 \\
\hline Bahrain & 11306 & 11993 \\
\hline Iraq & 57005 & 62308 \\
\hline Oman & 58082 & 62178 \\
\hline Saudi Arabia & 34557 & 36684 \\
\hline Turkey & 25899 & 27586 \\
\hline Nepal & 144212 & 152335 \\
\hline Sri Lanka & 358921 & 382265 \\
\hline Bhutan & 17503 & 18678 \\
\hline Indonesia & 35788 & 38278 \\
\hline Malaysia & 241767 & 256879 \\
\hline Philippines & 42867 & 47537 \\
\hline Singapore & 146180 & 154711 \\
\hline Vietnam & 15479 & 17416 \\
\hline China (Main) & 214799 & 230814 \\
\hline Japan & 261912 & 275827 \\
\hline Rep. of Korea & 135536 & 143505 \\
\hline Others & 233745 & 245322 \\
\hline Italy & 103767 & 103767 \\
\hline Spain & 62985 & 62985 \\
\hline UAE & 49143 & 49143 \\
\hline Iran & 38745 & 38745 \\
\hline Pakistan & 73900 & 73900 \\
\hline China (Taiwan) & 36314 & 36314 \\
\hline Bangladesh & 475863 & 475643 \\
\hline Nigeria & 66137 & 97940 \\
\hline Yemen & 23825 & 26463 \\
\hline Afghanistan & 170209 & 224077 \\
\hline Maldives & 58230 & 61816 \\
\hline Thailand & 122588 & 131311 \\
\hline Czech Republic & 12832 & 13683 \\
\hline
\end{tabular}

Table 3 Medical Tourist Arrivals in India, 2009 - 2015

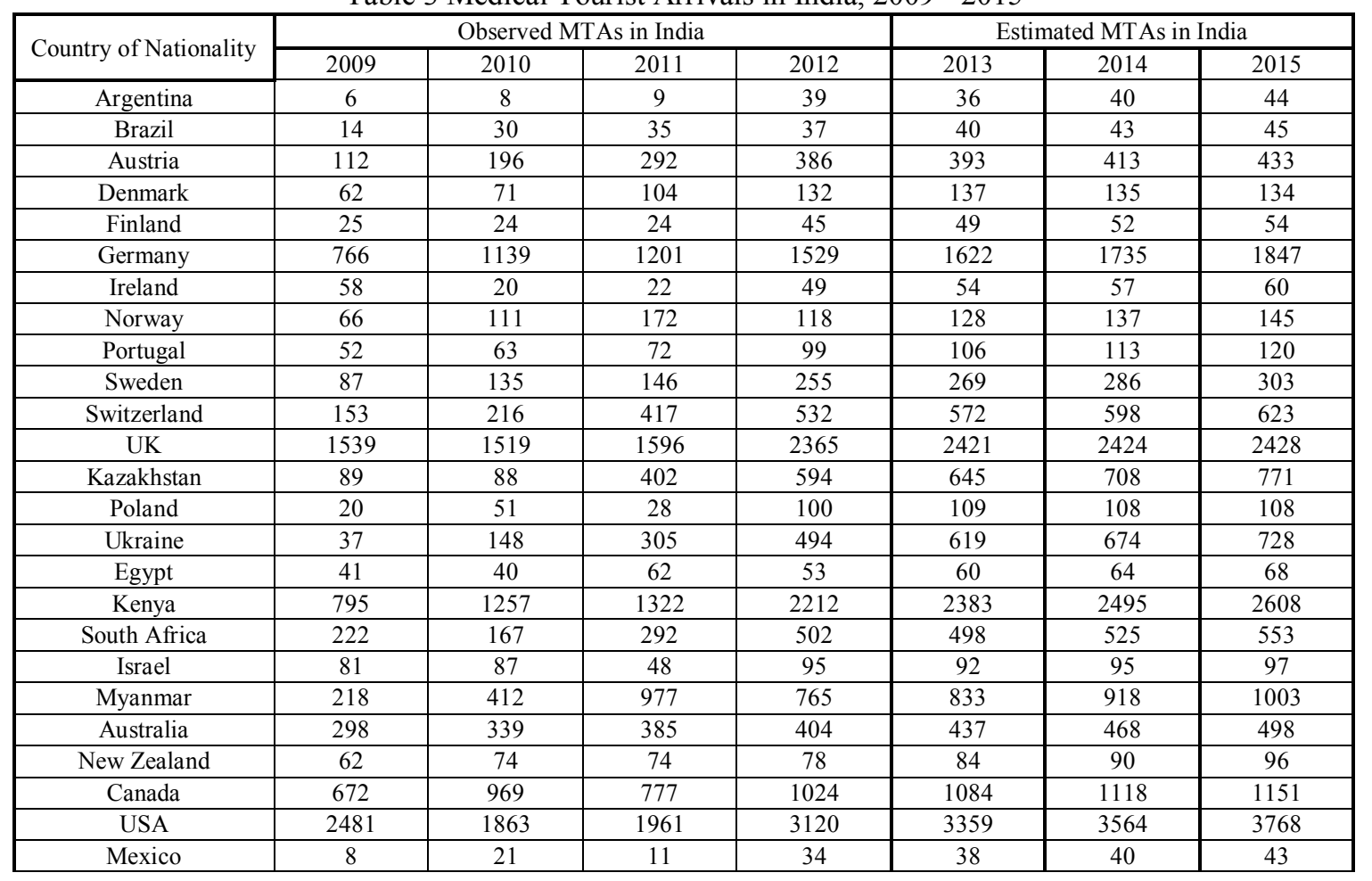


Forecasting the Demand for Medical Tourism in India

\begin{tabular}{|c|c|c|c|c|c|c|c|}
\hline Belgium & 70 & 38 & 40 & 43 & 45 & 48 & 51 \\
\hline France & 393 & 450 & 463 & 481 & 523 & 553 & 582 \\
\hline Greece & 13 & 22 & 22 & 22 & 24 & 26 & 27 \\
\hline Netherlands & 129 & 142 & 150 & 150 & 160 & 167 & 174 \\
\hline Russian Fed. & 95 & 488 & 2598 & 5858 & 6262 & 6919 & 7576 \\
\hline Sudan & NA & 401 & 715 & 866 & 961 & 1060 & 1160 \\
\hline Tanzania & NA & 1870 & 2200 & 2995 & 3101 & 3296 & 3492 \\
\hline Bahrain & 308 & 295 & 479 & 583 & 616 & 656 & 696 \\
\hline Iraq & NA & 6773 & 8996 & 12929 & 17217 & 18983 & 20749 \\
\hline Oman & 4913 & 5820 & 5559 & 5673 & 6154 & 6621 & 7088 \\
\hline Saudi Arabia & 622 & 756 & 1366 & 1349 & 1362 & 1451 & 1541 \\
\hline Turkey & 21 & 15 & 35 & 46 & 48 & 52 & 55 \\
\hline Nepal & 1687 & 1357 & 11913 & 1128 & 1225 & 1298 & 1371 \\
\hline Sri Lanka & 3840 & 5064 & 4894 & 4752 & 5369 & 5743 & 6116 \\
\hline Bhutan & 227 & 771 & 1007 & 748 & 800 & 858 & 915 \\
\hline Indonesia & 120 & 262 & 358 & 384 & 433 & 465 & 498 \\
\hline Malaysia & 1083 & 1612 & 1457 & 1175 & 1360 & 1451 & 1541 \\
\hline Philippines & 88 & 98 & 125 & 133 & 153 & 171 & 190 \\
\hline Singapore & 381 & 645 & 595 & 657 & 688 & 731 & 774 \\
\hline Vietnam & 6 & 7 & 10 & 11 & 14 & 15 & 17 \\
\hline China (Main) & 100 & 120 & 142 & 169 & 199 & 215 & 231 \\
\hline Japan & 125 & 168 & 194 & 220 & 248 & 262 & 276 \\
\hline Rep. of Korea & 70 & 96 & 109 & 109 & 128 & 136 & 144 \\
\hline Others & 3070 & 5196 & 4802 & 8108 & 1111 & 1169 & 1227 \\
\hline Italy & 156 & 188 & 303 & 296 & 311 & 311 & 311 \\
\hline Spain & 59 & 145 & 143 & 134 & 126 & 126 & 126 \\
\hline UAE & 3731 & 3184 & 4912 & 3458 & 4079 & 4079 & 4079 \\
\hline Iran & 208 & 296 & 304 & 287 & 271 & 271 & 271 \\
\hline Pakistan & 850 & 466 & 778 & 1317 & 1626 & 1626 & 1626 \\
\hline China (Taiwan) & 70 & 2 & 26 & 32 & 36 & 36 & 36 \\
\hline Bangladesh & 27196 & 35853 & 34766 & 37530 & 36375 & 36641 & 36625 \\
\hline Nigeria & 3264 & 6021 & 8988 & 10661 & 15538 & 19180 & 28403 \\
\hline Yemen & 571 & 478 & 1032 & 1959 & 2200 & 2502 & 2779 \\
\hline Afghanistan & 12057 & 5211 & 11201 & 15713 & 21333 & 28085 & 36973 \\
\hline Maldives & 34254 & 36694 & 30563 & 29904 & 32403 & 34530 & 36657 \\
\hline Thailand & 269 & 77 & 92 & 105 & 114 & 123 & 131 \\
\hline Czech Republic & 0 & 20 & 34 & 56 & 60 & 64 & 68 \\
\hline
\end{tabular}

\section{Endnotes}

${ }^{[i]}$ Data archived from India Tourism Statistics $(2003$ - 2012), published by Ministry of Tourism, Government of India.

\section{References}

[1] Shanmugam K.R, Medical Tourism in India - Progress, Opportunities and Challenges, Monograph 26/2013 MSE Working Paper, Madras School of Economics, Chennai, India, 2013.

[2] IMTJ, Medical Tourism Climate Survey 2014, Conducted for the International Medical Travel Exhibition and Conference, Dubai, Intution Communication Ltd. 2014.

[3] Huang Y.L., Forecasting the Demand for Health Tourism in Asian Countries using A GM (1, 1) - Alpha Model, Tourism and Hospitality Management, 18 (2), 2012, $171-181$.

[4] Fretchling D.C., Forecasting Tourism Demand - Methods and Strategies, (Butterworth Heinemann, Oxford, 2001).

[5] Cuhadar M., Modelling and Forecasting Inbound Tourism Demand to Istanbul - A Comparative Analysis, European Journal of Business and Social Sciences, 2 (12), 2014, $101-119$.

[6] Ibid.

[7] Ibid.

[8] Ibid.

[9] Ibid

[10] Ibid.

[11] Mishra, R. And Shailesh, K., Making Indian Healthcare Market a Global Medical Tourism Destination, IOSR Journal of Business and Management, 2 (4), 2012, $23-28$. 